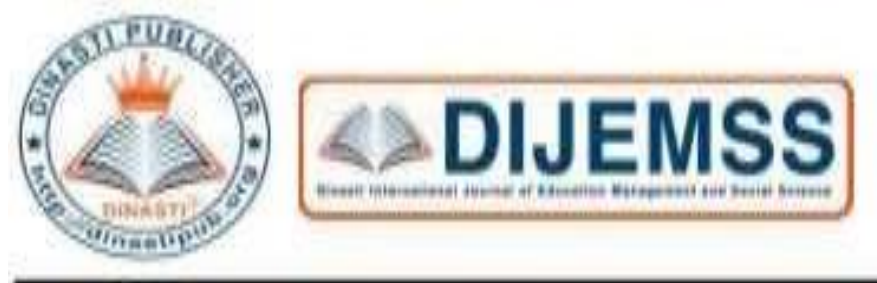

$+6281387654578$ 081387654578 (1)

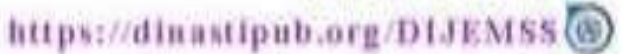
editoradinastipub.ors (6)

\title{
BUILDING PERFORMANCE SERVICE THROUGH TRANSFORMATIONAL LEADERSHIP ANALYSIS, WORK STRESS AND WORK MOTIVATION (EMPIRICAL CASE STUDY IN STATIONERY DISTRIBUTOR COMPANIES)
}

\author{
Chauhan Rahul ${ }^{1}$, Hapzi Ali ${ }^{2}$, Niknik Ahmad Munawar ${ }^{3}$ \\ ${ }^{1)}$ Parul University Of India, India \\ ${ }^{2)}$ Universitas Mercu Buana, Jakarta, Indonesia \\ ${ }^{3)}$ Research and Development Practitioners of PT.SHA, Jakarta, Indonesia
}

\begin{tabular}{|c|c|}
\hline $\begin{array}{l}\text { ARTICLE INFORMATION } \\
\text { Received: 24/11/2019 } \\
\text { Revised: } 27 / 11 / 2019 \\
\text { Issued: 30/11/2019 } \\
\text { Corresponding author: first author } \\
\text { E-mail: } \\
\text { rj88chauhan@gmail.com } \\
\text { hapzi.ali@gmail.com }\end{array}$ & $\begin{array}{l}\text { Abstract: This study aims to analyze: 1) } \\
\text { Transformational leadership influences work } \\
\text { motivation on employees of PT Meritindo Sejahtera } \\
\text { Jakarta. 2) Job stress influences work motivation on PT } \\
\text { Meritindo Sejahtera Jakarta employees. 3) } \\
\text { Transformational leadership influencesperformance } \\
\text { service of PT Meritindo Sejahtera Jakarta employees. } \\
\text { 4) work stress affects theperformance service of } \\
\text { PTemployees Merintido Sejahtera Jakarta. 5) work } \\
\text { motivation has an effect onperformance service of PT } \\
\text { Meritindo Sejahtera Jakarta employees. The research } \\
\text { method is: quantitative research that uses the survey } \\
\text { method in question is to explain the causal } \\
\text { relationships or correlations commonly referred to as } \\
\text { path analysis tools with analytical tools using the Lisrel } \\
\text { SEM Program 8.8. Respondents were } 199 \text { employees } \\
\text { at PT Meritindo Sejahtera Jakarta. The results of the } \\
\text { study are: 1) the influence of transformational } \\
\text { leadership on work motivation of PT Meritindo } \\
\text { Sejahtera Jakarta employees. 2) the insignificant } \\
\text { influence of work stress on work motivation on } \\
\text { employees of PT Meritindo Sejahtera Jakarta. 3) the } \\
\text { influence of transformational leadership } \\
\text { onperformance service on PT Meritindo Sejahtera } \\
\text { employees 4) the influence of work stress } \\
\text { onperformance service employeeon PT Meritindo } \\
\text { Sejahtera Jakarta employees. 5) the influence of } \\
\text { motivation onperformance service on PT Meritindo } \\
\text { Sejahtera employees. }\end{array}$ \\
\hline
\end{tabular}


Keywords: service performance, motivation, work stress and transformational leadership.

\section{INTRODUCTION}

This research was conducted at PT. Meritindo Sejahtera Jakarta as a Stationery distributor, located in ITC Cempaka Mas, Central Jakarta. Based on preliminary data obtained, it is known that the level of customer activation as a source of company turnover continues to decline every year. The following customer activation data per year PT. Meritindo Sejahtera Jakarta:

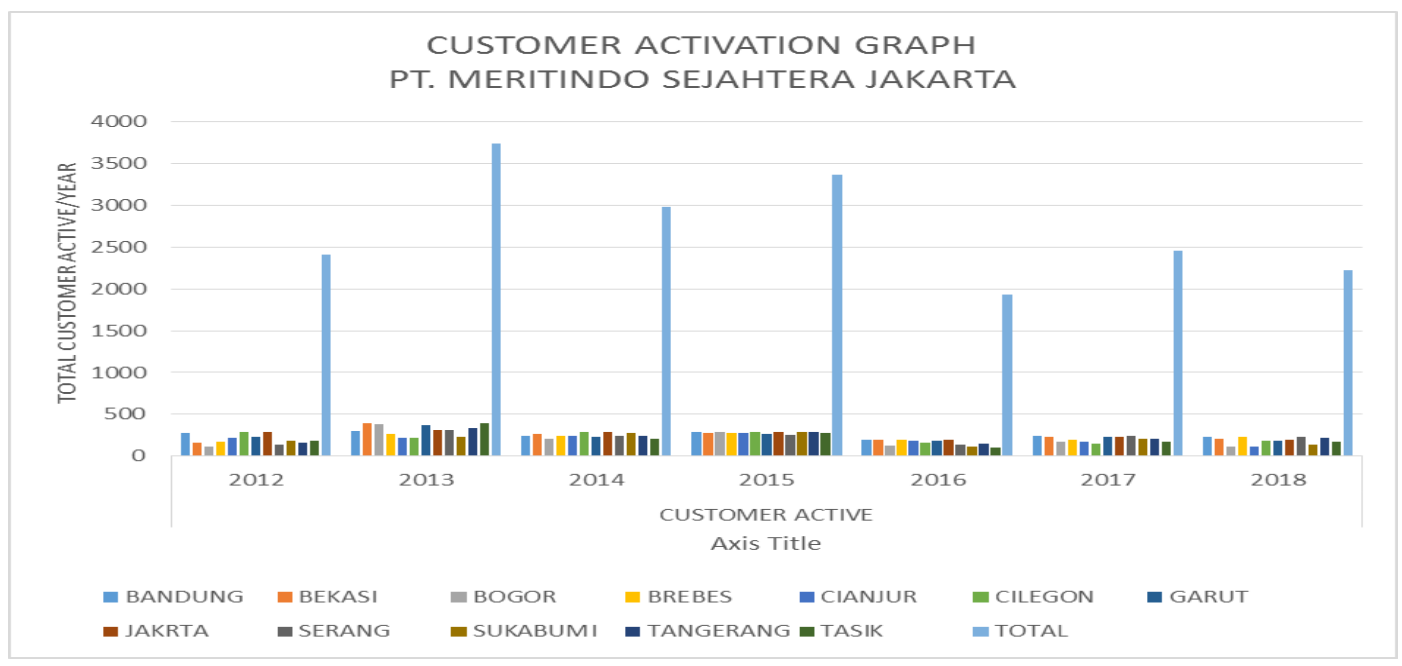

Picture 1. Drafik Customer (2012-2018)

Source: 2018 Sales \& Marketing Division The

Data above is a graph of active customer development PT. Meritindo Sejahtera Jakarta. Based on the table, it appears that customers who actively shop at PT. Meritindo Sejahtera Jakarta has decreased significantly each year, from the total customers in 2013 which reached 3742 customers in the form of resellers of PT. Merintindo Sejahtera Jakarta continues to decline to 2221 in 2018 . This is allegedly because the performance of employee services to customers is still not optimal. Maintaining key customers requires hard work from all elements in the company so that the company's service performance can be maintained. In addition to increasingly fierce business competition, of course the transformational leadership factor and stress due to work must be considered by the company so that employee motivation becomes triggered.

Many factors cause the company's service performance to customers to decline, resulting in many key customers turning to competing companies. But in this study, researchers are interested in examining and observing 3 main factors as research material, namely transformational leadership factors, work stress, employee motivation at work. These three factors are possible or suspected to cause the company's service performance factors to customers to decline.

Transformational leadership factor is the use of power and influence to direct the activities of flowers or subordinates towards the achievement of goals. That direction can 
influence the interpretation of followers of events, the organization of their work activities, their commitment to important goals, relationships with other followers, or their access to cooperation and support from other work units. While work stress is a factor caused when employees are not able to meet what are the demands of the job, and unclear what is the responsibility of the job. Stress is a condition of tension that creates a physical and psychological imbalance that affects the emotions, thought processes and conditions of an employee.

Another variable that is thought to influence the decline in the company's service performance is work motivation. Motivation as something that gives encouragement to individuals to do something desired work in accordance with the inspiration or desired individual. Individuals who have motivation such as getting energy to do the work while for individuals who do not do something work are considered to have no motivation. Based on the empirical background and literature described above, I am interested in conducting research under the title "BUILDING SERVICE PERFORMANCE THROUGH TRANSFORMATIONAL LEADERSHIP ANALYSIS, WORK STRESS AND WORK MOTIVATION(Empirical Case Study in Stationery Distributor Companies)".

\section{Formulation of the problem}

Based on this background, the problem to be investigated is how the influence of transformational leadership on performance, how the effect of work stress on employee performance at PT.Meritindo Sejahtera Jakarta, How does the influence of work motivation on employee performance of PT. Meritindo Jakarta, how the influence of transformational leadership on the motivation of the employees of PT. Merintindo Sejahtera Jakarta and how the effect of work stress on the work motivation of PT.Meritindo Sejahtera Jakarta employees.

\section{Research Objectives}

The purpose of this study is to determine the effect of transformational leadership, work stress on work motivation and service performance and the effect of work motivation on service performance of PT. Meritindo Sejahtera Jakarta.

\section{Benefits of research}

The expected benefits of this study are as follows:

1) Theoretical Benefits

This research is expected to broaden the knowledge of science, especially in the field of Human Resources management, especially in studies related to work stress and employee performance. In addition, this research is expected to be useful for other studies.

2) Practical Benefits

From the practical aspects of the use of this study to determine the effect of transformational leadership, work stress on work motivation and service performance as well as the effect of work motivation on service performance of PT. Meritindo Sejahtera Jakarta. 


\section{LITERATURE REVIEW}

\section{Service Performance}

Concept of performance is the value of a set of employee behaviors that contribute, both positively or negatively to the fulfillment of organizational goals (Colquitt, LePine and Wesson, 2009) [1]. Performance is a function of one's level of ability and motivation. This illustrates that performance is closely related to one's ability and motivation in working, (Slocum and Hellriegel, 2009) [2]. Whereas according to Bernardin and Russel (1998) [3], Performance is defined as a record of the results generated at a particular job function or activity over a period of time ". So in the opinion of Bernardin and Russel (2009), performance tends to be seen as the result of a work process whose measurements are carried out within a certain period of time. Performance is a service that is intangible, meaning that it cannot be seen, felt, smelled, heard, or touched before being consumed (Tjiptono, 2012: 29) [4]. Service performance is a result of the difference between expectations and the results obtained by the company as a result of employee performance (Dhar, 2015) [5]. Based on this service performance is the result of various factors that influence employees to get results / achieve the goals set together.

\section{Work Motivation}

The term motivation comes from the Latin word, namely: motive which means the cause, basic reason, basic thought of encouragement for someone to do or the main idea that always has a big influence on human behavior. Motive is sometimes interpreted as the needs, desires, impulses, gestures in a person. The motive is directed at the goal.

There are many theories about motivation. Among those stated by Kinicki and Kreitner (2008)[6] which defines being motivated means being moved to do something. Someone who does not feel the urge or inspiration to act is thus marked as unmotivated, while someone who is energized or activated to achieve a goal is considered motivated. So motivation can be explained as something that gives encouragement to individuals to do something desired work in accordance with the inspiration or desire of the individual. Individuals who have motivation such as getting energy to do the work while for individuals who do not do something work are considered to have no motivation. Motivation is part of individual behavior that plays a role in providing encouragement to take / do something (decision). Pressure in the business world has increased in various sectors so that individual performance is very important, especially related to employee motivation.

Based on the explanation above, it can be synthesized that work motivation is an impulse that is in a person to do a job with indicators such as understanding service, responsiveness, problem solving, service speed, situation adaptation, initiative, service attitude, self-appearance and compliance.

Motivation can also be defined to achieve something difficult. To master, manipulate, or arrange physical objects, humans, or ideas. To do this as quickly and independently as possible. To overcome obstacles and achieve high standards. To excel from oneself. To rival and surpass others. To increase self-esteem by successful talent training, (Kinicki and Kreitner, 2008) [7]. So motivation is the drive to accomplish something difficult. To become an expert, manipulate or manage goals, humanity or ideas. To do something as fast and as 
freely as possible. To surpass challenges and try new standards. To surpass yourself. To rival and surpass the others. To increase self-esteem by training the success of talent.

According to Siswanto (2009) [8], motivation is every feeling or will and desire that greatly influences the individual's will so that the individual is encouraged to behave and act; the influence of forces that give rise to individual behavior; every action or event that causes a change in someone's behavior; and the process that determines the movement or behavior of individuals towards the goal.

Based on the explanation above, it can be synthesized that work motivation is an impulse that is in a person to do a job with indicators such as instilling idealism, providing inspiration, providing intellectual support and wisdom.

\section{Transformational}

Leadership Leadership is an important aspect in moving an organization. Graffeo (2019) [9] states that the essence of leadership is the ability to change an idea into a result that has a significant impact, so that from this statement the organization can move forward while experiencing setbacks caused by various factors where one of them is leadership. The leader is like a captain for ships that try to sail across the vast ocean, so as a leader must know where the goals of the organization will go.

According to Banks (2016) [10] transformational leadership has 4 dimensions, namely idealized influence, which is the tendency of individuals to encourage others to be similar or in accordance with themselves, inspirational motivation is a condition where individuals provide an idea or inspiration so that others follow it, intellectual stimulation characterizes namely behavior where individuals provide challenges to argue or take other risks to their employees and individual consideration is behavior where individuals try to meet and understand the needs of their employees.

According to Mickahail (2019) [11] transformational leadership is a creative leader who will continue to look for ways to build a more diverse and inclusive workforce that supports innovation and creativity. Leaders need to demonstrate insight, agility, integrity, and courage to build the respect of their followers and develop an organizational culture that is enhanced by a diverse workforce. "

Referring to the understanding of transformational leaders above, it can be explained that creative leaders will continue to look for ways to build a workforce that has a variety of different and inclusive backgrounds and supports innovation and creativity. This is in line with research conducted by Suharyono and Ali $\mathrm{H}$ entitled, " The Effect of Motivation, Discipline and Leadership Style on Work Performance of the Social Workers and Transmigration Offices of Batang Hari Regency".

Based on the description above, it can be synthesized that transformational leadership is a leader who can encourage others to be similar or in accordance with him, inspirational motivation is a situation where individuals give an idea or inspiration so that others follow it, intellectual stimulation characterizes the behavior in which individuals give the challenge to argue or take other risks to employees and individual consideration is the behavior in which individuals try to meet and understand the needs of their employees. Transformational leaders must have insight, agility, integrity, and courage to build respect from their employees and develop an organizational culture that is enhanced by a workforce with diverse backgrounds. 
Indicators of a transformational leader such as instilling idealism, providing inspiration, providing intellectual support, and wisdom inherent in him.

\section{Work Stress (Work Stress)}

Opinions of experts related to the definition of work stress is very diverse. According to Gibson et al. [12], "work stress is an adjustment response mediated by individual differences and / or psychological processes that are a consequence of any external (environmental) action, situation, or event that establishes psychological and physical demands. excessive to someone ".

Meanwhile, Eriyanto [13], explained that "work stress is a status experienced when there is a mismatch between the demands faced and the capabilities possessed". Then, Rivai [14] argues that "work stress is a condition of tension that creates a physical and psychological imbalance that affects the emotional thinking patterns and conditions of an employee".

According to Robbins [15], "work stress is a dynamic condition in which an individual is confronted with an opportunity, obstacle, or demand that is associated with what is very desirable and the results are perceived as uncertain and important". Meanwhile, according to Hasibuan [16], "stress is a condition of tension that affects one's emotions, thought processes, and conditions. People who experience stress become nervous and feel chronic worries. They often become angry, aggressive, unable to relax, or show uncooperative attitudes ".

Based on the description above, it can be synthesized that work stress is where a condition of an employee experiencing psychological or physical disorders in dealing with a problem or job. A condition where employees experience a mental or physical pressure that cannot keep up with the demands of the company. Job stress can be seen from symptoms such as unstable emotions, feeling uneasy, like to be alone, insomnia, anxiety, tension, nervousness, increased blood pressure, and experiencing indigestion (Semaksiani A, Et.al: 2019) [17]

\section{Conceptual Framework}

\section{The influence of transformational leadership on work motivation}

Transformational leadership is a leader who can encourage others to be similar or in accordance with him, inspirational motivation is a situation where individuals give an idea or inspiration so that others follow it, intellectual stimulation characterizes the behavior where individuals provide challenges to the opinion or take other risks to their employees and individual consideration that is the behavior in which individuals try to meet and understand the needs of their employees. This is supported by previous research conducted by Tucunan et al. (2014) [18] that influential Transformational leadership can inspire and motivate subordinates to show better performance for individual employees. Likewise research conducted by Pradita (2017) [19] with the title "The effect of compensation, leadership style and characteristics of marketers on the motivation and performance of marketers in pt. Bank Rakyat Indonesia (Persero) tbk. Jombang Branch". Found a correlation between the positive influence of transformational leadership on employee work motivation. 
Research conducted by Zareen et al. (2015) [20] with the title "Impact of transactional, transformational and laissez-faire leadership styles on motivation: A quantitative study of banking employees in Pakistan". States that transformational leadership transformational leadership has a positive effect on motivation. Carl Deschamps.et.al(2016) [21] with the title " Transformational Leadership and Change: How Leaders Influence Their Followers Motivation Through Organizational Justice". That Transformational leadership can influence followers to act and act in influencing organizational goals. It is said in the results of his research that Transformational Leadership positively influences the motivation of individual followers.

\section{Effect of work stress on work motivation}

According to Rivai (2004) [22], work stress is a condition of tension which affects one's emotions, thoughts, and physical condition. The level of stress that occurs in a company can cause a lack of employee motivation at work, as the main actors in an organization the human element needs to be maintained through various means. This is supported by Amela's research, Loghan[23] suggested that work stress is an undesirable reaction where he experiences great pressure or workload given to him. Thus, the work pressure of employees at PT. Surya Raya Lestari II in Central Mamuju Regency must be in accordance with work motivation so that employees can work well.

\section{The Effect of Transformational Leadership on Service Performance}

Transformational leadership style can improve the performance of its employees. This influence is very central to the performance of an employee. Good and bad performance of an employee one of the factors is the attitude and behavior of a leader. This is in accordance with the results of research conducted by Kharis (2015) [24] with the title, " The influence of transformational leadership style on employee performance with work motivation as an intervening variable (study on employees of the Malang branch of Bank Jatim)". In his research results, Kharis found the relationship or influence of a leader's leadership style on employee performance both directly and through the inspiration or motivation of individual employees to emulate the work ethic of superiors. Tampi (2014) [25] with the title "The Effect of Leadership Style and Motivation on Employee Performance at PT. Bank Negara Indonesia, tbk (regional sales of Manado). "In his research he proved the analysis of the influence of transformational leadership styles on service performance through individual employee motivation. But in the results of his research explained that the results of his analysis proved significantly that transformational leadership has a positive effect on employee performance.

\section{Effect of work stress on Employee Performance}

Job stress is an important aspect for an organization or company, especially its relation to employee performance. The problem of stress, basically, is often associated with understanding work stress that occurs in the work environment, namely in the process of interaction between an employee and his work, because the impact of stress at work can affect life, health, productivity, performance and income. This is supported by the results of research conducted by Masie.Rachel,et.al(2018) [26] with the title of the study, "The Effect 
of Job Stress on Employee Performance in the Manado It Center Management Office". In his research Masie,et.al(2018) found a significant effect of employee work stress factors on employee performance. It is said that work stress factor is one of the factors that positively and significantly influences the performance of an employee. Likewise, research conducted by Fitriah and Sofi.et.al (2016) [27] with the title "The Effect of Work Stress On Employee Performance at PT. Simpatindo Multi Media Bandung"The results of research conducted by Masie, et.al (2016) confirm that work stress has a significant effect on employee performance. Research conducted by Usailan Qomar (2017) [28] with the title " The Effect of Work Stress on Employee Performance in the Department of Revenue, Finance and Assets of Musi Banyuasin Regency". confirm that work stress has a positive and significant effect on employee performance. The results of a study conducted by Dewi \& Wibawa (2016) [29] confirm that work stress has a positive and significant effect on employee performance.

\section{The influence of work motivation on Employee Performance}

Research results Tindow et al. (2014) [30] with the title " Work Discipline, Motivation and Compensation for Influence on Employee Performance at PT. Bank Sulut Calaca Branch". said that motivation has a positive effect on performance. Further research conducted by Hanafi \& Yohana (2017) [32] with the title "The influence of motivation, and work environment, on employee performance, with job satisfaction as a mediating variable at PT BNI Life Insurance". Found that motivation has a positive effect on performance.

Based on the explanation above about the flow of thought between research variables by referring to the results of previous research and expert opinion, it can be illustrated through the framework of the research model as follows:

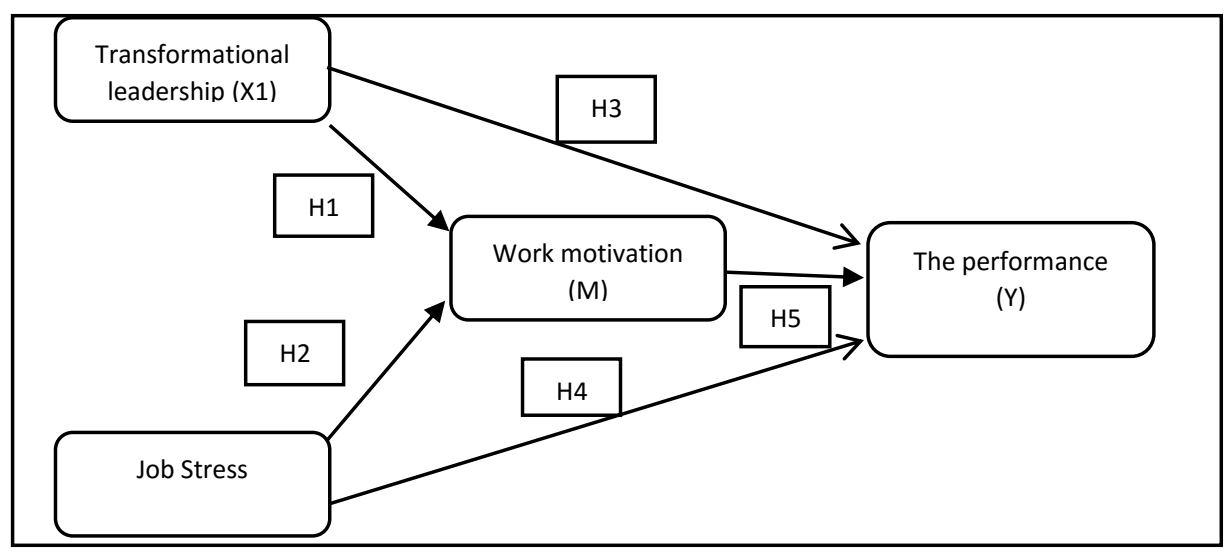

Ficture 2. Concetual Framework

\section{Research Hypothesis}

1) H1: Transformational Leadership has a positive and significant effect on employee work motivation at PT. Meritindo Sejahtera Jakarta

2) H2: Job stress has a positive and significant effect on employee work motivation at PT. Meritindo Sejahtera Jakarta

3) H3: Work Motivation has a positive and significant effect on service performance at PT. Meritindo Sejahtera Jakarta

4) H4: Job stress has a positive and significant effect on service performance 
5) H5: Transformational Leadership (LTRAN) has positive and significant effect on Service Performance (SERPER)

\section{RESEARCH METHODS}

This research is a quantitative study using survey methods. The intended survey research is to explain causal relationships or correlations which are commonly referred to as path analysis.

The affordable population of this research is all employees of PT. Meritindo Sejahtera Jakarta as many as 199 employees having their address at ITC Cempaka Mas, Central Jakarta. The sampling technique used is saturated sample, this technique was chosen based on the consideration that the researcher will use data analysis techniques using Lisrel which requires a lot of research samples. Data analysis tool used in this study is to use SEM (structural equation modeling).

\section{FINDINGS AND DISCUSSION}

\section{Findings}

\section{Ful model SEM}

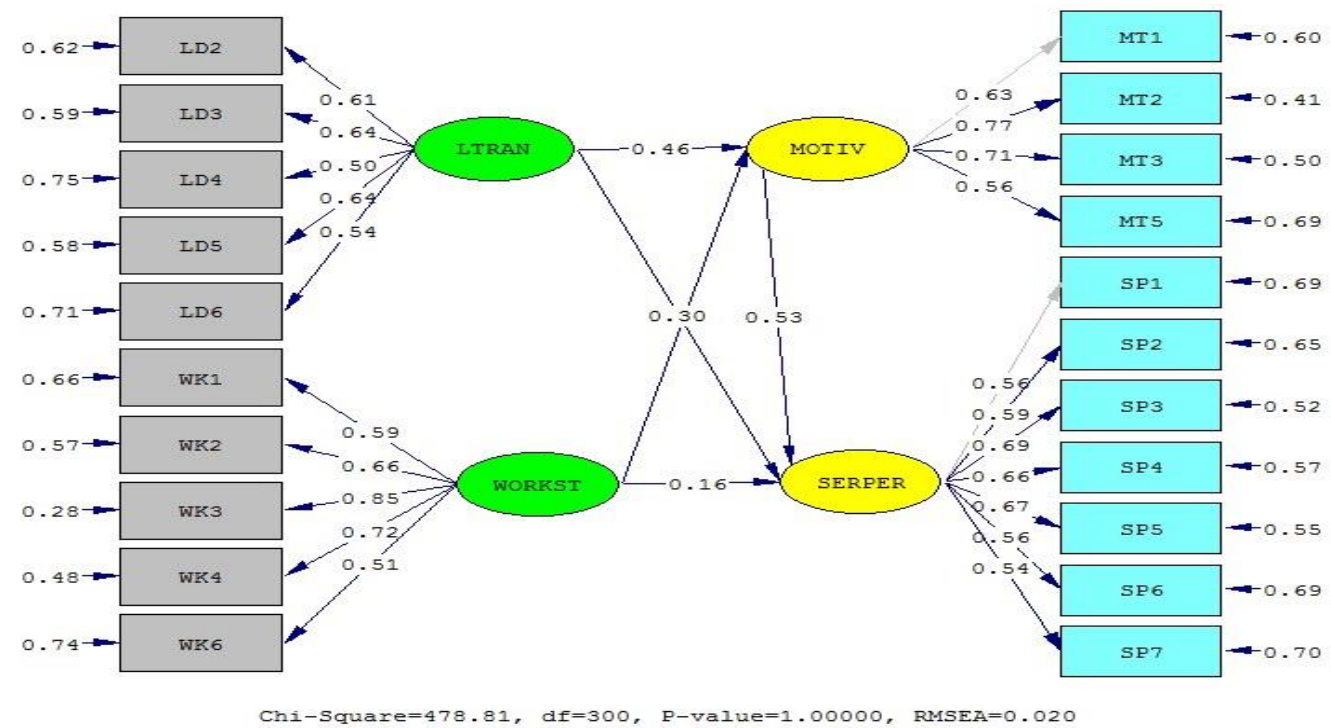

Picture 3. Full model SEM Standaridize Solution

Source: Data processed by author (2019)

\section{Comfirmatory Factor Analysys}

Test Validity and Reliability of 1st Order CFA

Table 1. Test Validity and Reliability of 1st Order CFA Measurement Model

\begin{tabular}{|c|c|c|c|c|c|c|c|}
\hline \multirow[b]{2}{*}{ Laten Variabel } & \multirow{2}{*}{$\begin{array}{l}\text { Variabel } \\
\text { Manifes }\end{array}$} & Estimation & Critical & \multirow[b]{2}{*}{ Decision } & Estimation & \multirow{2}{*}{$\begin{array}{l}\text { Critical } \\
\text { Value }\end{array}$} & \multirow[b]{2}{*}{ Decision } \\
\hline & & $\begin{array}{l}\text { Factor } \\
\text { Loading }\end{array}$ & $\begin{array}{l}\text { Faktor } \\
\text { Loading }\end{array}$ & & $\begin{array}{l}\text { Construct } \\
\text { Reliabilty(CR) }\end{array}$ & & \\
\hline \multirow{4}{*}{$\begin{array}{l}\text { Transformational } \\
\text { Leadership (LTrans) }\end{array}$} & LD1 & 0,45 & 0,5 & Drop & \multirow{4}{*}{0,75} & \multirow{4}{*}{$0.5-0.70$} & \multirow{4}{*}{ Reliable } \\
\hline & LD2 & 0,61 & 0,5 & Valid & & & \\
\hline & LD3 & 0,64 & 0,5 & Valid & & & \\
\hline & LD4 & 0,50 & 0,5 & Valid & & & \\
\hline
\end{tabular}




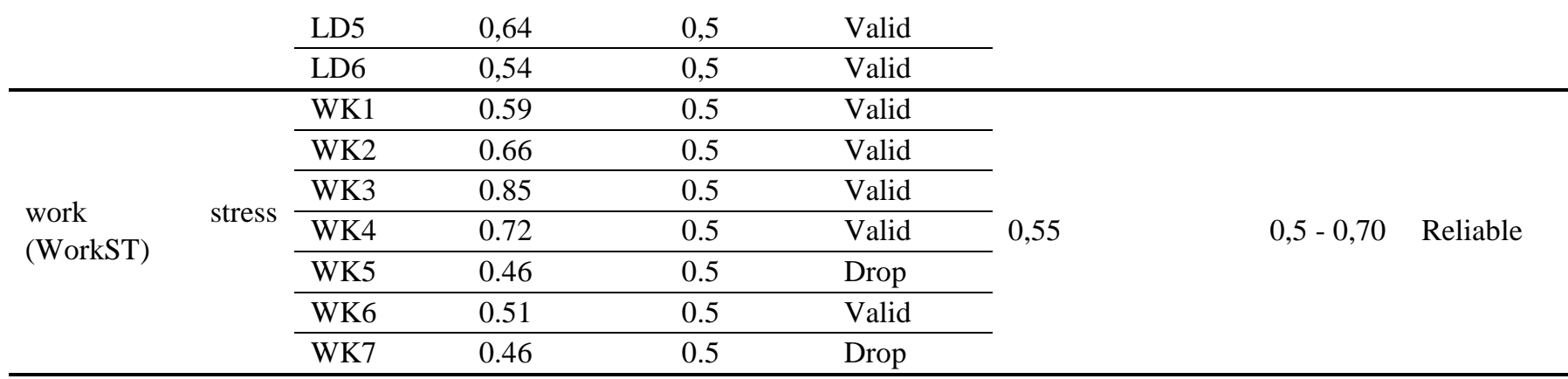

Sumber : Olah Data (2019)

In the first order construct the Transformational Leadership (LTRAN) variable has 6 manifest variables and one factor variable. After testing the validity of the variable, there is a manifest variable on the leadership latent variable, namely the LD1 indicator variable with a factor loading value below the required value of $\geq 0.50$ so it must be dropped from the model because it does not represent the statement of the respondent. While the five other manifest variables meet the criteria for goodness of fit with a score loading factor $\geq 0.50$ so that it is declared valid in the results of the variable validity test. Similarly, the requirements must meet the specified reliability value that is with avalue critical reliability of 0.5 to 0.70 . In this reliability test all manifest variables or observed variables in the latent variable Transformational Leadership outside the observedvariable LD1dropped from the model have a Construct Reliability(CR) value between 0.5 to 0.70 or between the values above are acceptable to Considered Very Good.

In the process of testing the validity and reliability of the first order construct the Work Stress(WorST) variable has 7 Observed variables, it is known that of the seven observed variables, two manifest variables namely WK5 and WK7 have a Loading Factor value $\leq 0.5$ so that they must be eliminated from the model because the researchers consider the statements in these variables do not represent the statements of the respondents. While the five other manifest variables such as WK1, WK2, WK3, WK4, and WK6 meet the required factor loading value standards between 0.5 and 0.7 so that the five manifest variables are valid. Furthermore, in testing the reliability of the five manifest variables has a Construct Reliability(CR) value between 0.5 to 0.7 in accordance with what was said by Hair et.al(2010)[34) that; " Values more than 0.7 are considered very good, though, the level of 0.5 and above are acceptable".

Tabel 2. Test Validity and Reliability of 1st Order CFA Measurement Model

\begin{tabular}{|c|c|c|c|c|c|c|c|}
\hline \multirow{2}{*}{$\begin{array}{c}\text { Laten } \\
\text { Variabel }\end{array}$} & \multirow{2}{*}{$\begin{array}{l}\text { Variabel } \\
\text { Manifes }\end{array}$} & \multirow{2}{*}{$\begin{array}{c}\text { Estimation } \\
\text { Factor } \\
\text { Loading } \\
\end{array}$} & \multirow{2}{*}{$\begin{array}{c}\text { Critical } \\
\text { Faktor } \\
\text { Loading }\end{array}$} & \multirow[b]{2}{*}{ Decision } & \multirow{2}{*}{$\begin{array}{c}\text { Estimation } \\
\text { Construct } \\
\text { Reliabilty }(\mathrm{CR}) \\
\end{array}$} & \multirow{2}{*}{$\begin{array}{l}\text { Critical } \\
\text { Value }\end{array}$} & \multirow[b]{2}{*}{ Decision } \\
\hline & & & & & & & \\
\hline \multirow{4}{*}{$\begin{array}{c}\text { Motivation } \\
\text { (Motiv) }\end{array}$} & MIT1 & 0.63 & 0.5 & Valid & \multirow{4}{*}{0,91} & \multirow{4}{*}{$0,5-0,70$} & \multirow{4}{*}{ Reliable } \\
\hline & MIT3 & 0.73 & 0.5 & Valid & & & \\
\hline & MIT4 & 0.47 & 0.5 & Drop & & & \\
\hline & MIT5 & 0.56 & 0.5 & Valid & & & \\
\hline \multirow{5}{*}{$\begin{array}{c}\text { Service } \\
\text { Performance } \\
\text { (Serper) }\end{array}$} & SP3 & 0.69 & 0.5 & Valid & \multirow{5}{*}{0,88} & \multirow{5}{*}{$0,5-0,70$} & \multirow{5}{*}{ Reliable } \\
\hline & SP4 & 0.66 & 0.5 & Valid & & & \\
\hline & SP5 & 0.67 & 0.5 & Valid & & & \\
\hline & SP6 & 0.56 & 0.5 & Valid & & & \\
\hline & SP7 & 0.54 & 0.5 & Valid & & & \\
\hline
\end{tabular}


Source: Data Processing (2019)

Testing the validity and reliability of the first order construct Motivation variable shows that the manifest variable of Motivation namely MT4 must be eliminated from the model because it does not meet the standard factor loading value that is recommended at 0.05. While the four observed variables of latent variables Motivation meets the standard loading factor value $\geq 0.05$ so that the four manifest variables such as MT1, MT2, MT3 and MT5 can be said to be valid. Likewise in the reliability test the four manifest variables have Construct Reliability (CR) values $\geq 0.5$ and 0.7 so that they can be considered acceptable and considered very good, because the values of the four manifest variables are included in acceptable and considered very good groups, it can be concluded that the manifest variable is reliable .

Furthermore, from the results of testing the validity and reliability of the first order construct Service Performance variable (SERPER) with 7 manifest variables namely SP1, SP2, SP3, SP4, SP5, SP6, and SP7 it is known that all manifest variables have the loading factor values above the required or the same with a critical loading factor value so that all variables can be said to meet the requirements to be categorized valid. Construct Reliability (CR) value on the seven manifest variables of the Service Performance (latent variableSERPER)shows above the Critical Value that is 0.5 to 0.7 or between acceptable value with considered very good.

The following are the Fit Model Indicators which are illustrated in the table below:

Tabel 3. Indikator Fit Model

\begin{tabular}{ll}
\hline Item & Statement \\
\hline Transformational leadership (KTRAN) \\
\hline LD2 & $\begin{array}{l}\text { Every time my boss gives me an understanding of the } \\
\text { importance of work ethic values }\end{array}$ \\
\hline LD3 & $\begin{array}{l}\text { My boss always believes that I can complete the work targeted } \\
\text { at me }\end{array}$ \\
\hline LD4 & My boss always gives direction on the quality of work \\
\hline LD5 & $\begin{array}{l}\text { My boss was able to solve problems in a way I had never } \\
\text { thought of before }\end{array}$ \\
\hline LD6 & $\begin{array}{l}\text { My superiors always provide opportunities to correct mistakes } \\
\text { made at work }\end{array}$ \\
\hline
\end{tabular}

\begin{tabular}{|c|c|}
\hline \multicolumn{2}{|c|}{ Stres Kerja } \\
\hline WK1 & I am always restless when things go wrong \\
\hline WK2 & $\begin{array}{l}\text { My emotions often peak when they are no longer able to bear } \\
\text { the workload }\end{array}$ \\
\hline WK3 & Physical fatigue causes my concentration in work to decrease \\
\hline WK4 & $\begin{array}{l}\text { I often have difficulty falling asleep because of problems that } \\
\text { occur at work }\end{array}$ \\
\hline WK6 & I am often desperate in solving problems that occur in my work \\
\hline
\end{tabular}




\begin{tabular}{ll}
\hline Motivasi & \\
\hline MT1 & I am always motivated by seeing how my boss works \\
\hline MT2 & I feel very enough with the salary given by the company today \\
\hline MT3 & I always try to reach the target set by the company \\
\hline KT5 & I am willing to be assigned by the company anywhere \\
\hline KINERJA & LAYANAN \\
\hline SP2 & I am very familiar with my company's SOP \\
\hline SP3 & I understand the needs of the company's customers \\
\hline SP4 & I am always quick in handling customer complaints \\
\hline SP5 & I always give the best solution to customers \\
SP6 & $\begin{array}{l}\text { Customer satisfaction for company service has always been my } \\
\text { concentration }\end{array}$ \\
\hline SP7 & $\begin{array}{l}\text { I always adapt to the character of the company's customers for } \\
\text { the satisfaction of the company's customers }\end{array}$ \\
\hline
\end{tabular}

\section{Source: Processed by researchers (2019)}

\section{Second Order CFA (2ndCFA) \\ Model Match Test}

After the first stage produces a CFA model with good validity and reliability, the second stage is carried out. Second Order CFA (2ndCFA) shows the relationship between latent variables at the first level as indicators of a second level latent variable. In this second stage, researchers add the original structural model to the first CFA model to produce a hybrid model. Furthermore, the hybrid model will be analyzed and evaluated for the overall suitability of the model using Goodness of Fit (GOF).

To find out whether the research model is fit or not, the results of the model fitness test (carried outgoodness of fit test) areby looking at the values on the predetermined criteria. To find out whether the full SEM model is fit or not it is necessary to test values such as RMSEA, GFI, CFI, CMIN / DF, Std RMR, NFI, NFI RFI and AGFI values.

Table 4. SUMMARY INDICATORS GOODNESS OF FIT INDEX (GOFI)

\begin{tabular}{llll}
\hline $\begin{array}{l}\text { GOFI } \\
\text { INDICATORS }\end{array}$ & $\begin{array}{l}\text { STANDARD VALUE } \\
\text { FOR GOODNESS OF } \\
\text { FIT }\end{array}$ & $\begin{array}{l}\text { CALCULATE } \\
\text { RESULTS }\end{array}$ & CONCLUSION \\
\hline RMSEA & $\leq 0.08$ & 0.020 & Fitted \\
\hline NFI & $\geq 0.05$ & 0.90 & Fitted \\
\hline NNFI & $\geq 0.90$ & 0.93 & Fitted \\
\hline CFI & $\geq 0.90$ & 0.94 & Fitted \\
\hline IFI & $\geq 0.90$ & 0.94 & Fitted \\
\hline RFI & $\geq 0.90$ & 0.93 & Fitted \\
\hline
\end{tabular}




\begin{tabular}{llll}
\hline Std RMR & $\leq 0.05$ & 0.034 & Fitted \\
\hline GFI & $\geq 0.90$ & 0.93 & Fitted \\
\hline AGFI & $\geq 0.90$ & 0.94 & Fitted \\
\hline
\end{tabular}

Source: Processed by researchers (2019)

Based on the results of the above analysis, it is obtained that the overallestimation results GOF ( goodness of fit) are categorized as Fit, so it can be concluded that the model is fit . That is, the sample covariance matrix is not very different from the estimated covariance matrix. This test is conducted to evaluate whether the model produced is amodel fit or not. From the printed output generated by the estimation of themeasurement 2ndCFA in theprogram Lisrel, analysis of the suitability of the whole model can be seen from the statistical figures as follows:

a.Chi-square value is 478.82 , with a df value of 300 while a p value $=1.00>0.05$. Judging from these results, where the comparison between the Chi-square value with df is $<2$ and the value of $\mathrm{P}>0.05$, it can be interpreted that this result shows a very good match because the model requirements have been met, if the comparison ofvalues Chi Square with $d f<2$ and $p>0.05$ then the model match conditions have been met.

b.The NFIof 0.90 valuehas fulfilled the model match requirements because the NFI value is greater than the required value $\geq .0 .05$, based on the NFI value, it can be concluded that the overall fit of the model is good, the high Normed Fit Index (NFI) indicates a good fit. When FT $=$ FI, NFI equals zero, and FT equals 0 and NFI equals one, it shows that the target model is the best fit for the independent model.

c.NNFI value of 0.93 indicates that the model is fit where the requirements are determined that the value of NNFI must be $\geq 0.90$. NNFI value of 0.93 is the limit value between the value of $0.90 \leq$ NNFI $<0.95$ and usually can be interpreted to indicate an acceptable threshold of fit. NNFI value of 0.93 is in the range of fit values between $0.90 \leq$ NNFI $<0.97$ can be interpreted as an acceptable fit measure.

d.Value of CFI (Comparative Fit Index) generated by 0.94 . This value is still in the required value range from 0 to 1 . A high CFI value indicates a more fit model.

e.Furthermore, the RMSEA value is 0.020 which means that the fit of the model is good or good fit and $90 \%$ confidence interval of RMSEA $(0.020 ; 0.081)$ or close to zero, and the RMSEA value is still in the range of intervals so that the RMSEA has good accuracy. A good RMSEA value is $\leq 0.05$ close fit and $0.05<$ RMSEA $\leq 0.08$ good fit. Whereas if the RMSEA value between 0.08 to 0.10 is marginal fit and $>0.10$ indicates poor fit. $P$-Value for test of close fit $($ RMSEA $<0.05)=0.00<0.50$, then the overall fit of the model is not good, $p$-value the desiredfor test of close fit is $\geq 0.50$.

f.The resulting IFI (Incremental Fit Index) value is 0.94 where this value is greater than the value required by the fit model that is $\geq 0.90$. The IFI value can be analogous to the $R^{2}$ value. A zero value indicates a poor fit model while a value of one indicates the best fit model

g.The RFI (Relative Fit Index) value is a measure of model fit that compares results from the target model or the proposed model with the baseline model (null) per degree of freedom $(d f)$. IFI value $\geq 0.90$ is an indication of a good fit model. While the value of $0.80 \leq \mathrm{NNFI}$ 
$<0.90$ is often said to be a cutoff value. From the results of this data processing produces an IFI value of 0.93 which means that the model indicates a good fit.

h.Std.RMR value of 0.34 that this model can be concluded fit. Std.RMR value $\leq 0.05$ indicates good model ability in terms of matching / fit data (good fit), while $0.05<$ Std.RMR $\leq 0.1$ including acceptable fit. But StdRMR $>0.1$ indicates poor model ability to match / fit data (poor fit)

i.GFI value of 0.93 that the model is suitable where the conditions of the model are said to match the GFI test is $\geq 0.90$.

j.AGFI values range between 0 and 1 . AGFI values $\geq 0.90$ indicate the ability of a good model to match or fit data ( good fit). Judging from the results of the above output with the AGFI value of 0.94 , it can be interpreted that this model is fit or the data fit is fit.

\section{Hypothesis testing}

To test the hypothesis it is necessary to look at the structural equation of the SEM model of the study contained in Figure 1 and Figure 4. Where the SEM model consists of 2 structural equation models as follows:

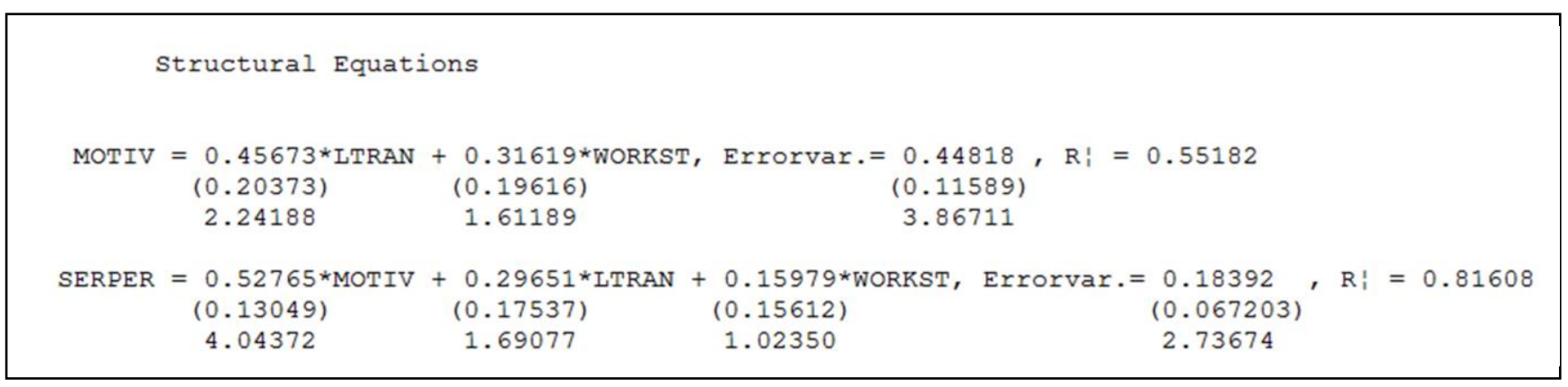

\section{Picture 4. Persamaan Struktural}

Source: Processed by researchers (2019)

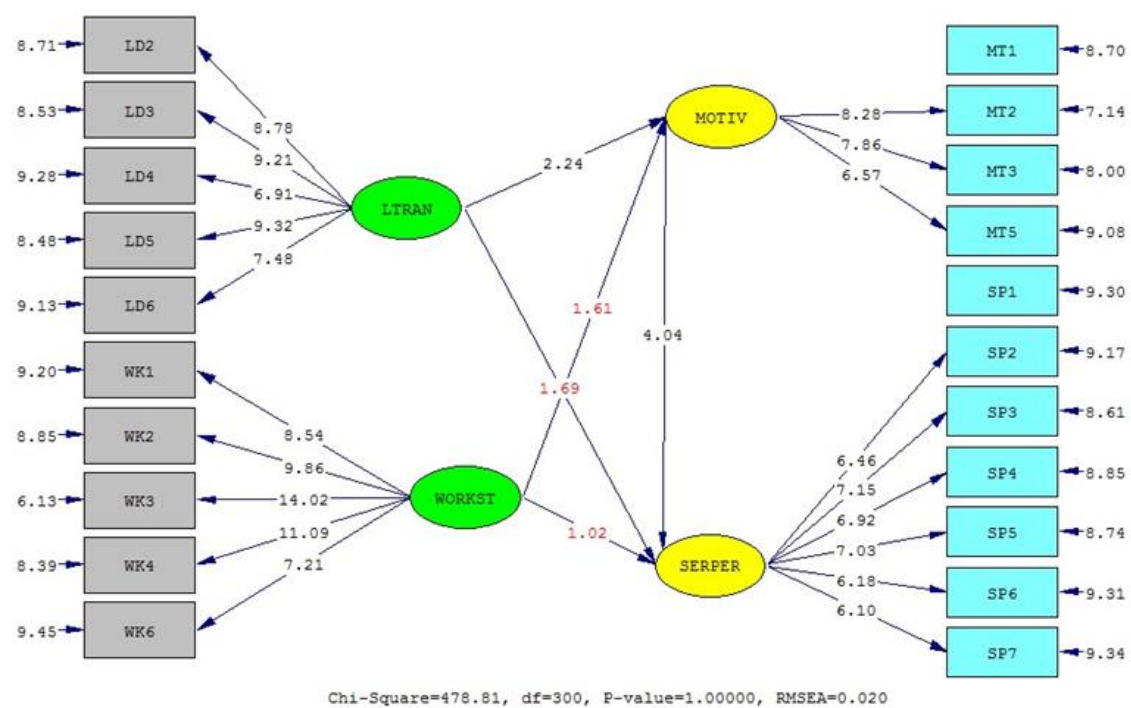

Picture 5. Full model SEM T-Value

Source: data processed by researchers (2019) 
To test the significance of the coefficient of influence between latent variables, it can consult the $Z$ value of the two tailed test table at $\alpha=0.05$ then the probability value $Z=1$ - ( $\alpha$ / 2) $=1-(0.05 / 2)=0.975$. Judging from the $Z$ table the value of 0.975 obtained a score of 1.96. A $\mathrm{Z}$ score of 1.96 is set as a critical value for significance testing.

\section{Direct Influence (DCE), Indirect (ICE) and Total Influence (TCE)}

Direct and indirect influence tests are performed to determine whether there are direct or indirect effects (DCE) of independent variables that affect the dependent variable. Based on the results of data analysis it can be seen the direct effect (DCE) of the Transformational Leadership variable (LTRAN) on Motivation (MOTIV) of 0.46 with a T-value of 2.24, the direct effect of the Transformational Leadership variable (LTRAN) on Service Performance (SERPER) of 0.30 with a T-value 1.69. The direct effect of Work Stress (WorkST) on Motivation is 0.30 with a T-Value of 1.62, the direct effect of Work Stress (WorkST) on Service Performance (SERPER) of 0.16 with a T-value of 1.02 and direct influence (DCE). Motivation (MOTI) on Service Performance (SERPER) of 0.16 with a T-value of 4.04. While the indirect effect (ICE) of Transformational Leadership (LTRAN) on Service Performance through Motivation is 0.244 . The indirect effect (ICE) of the Work Stress variable (WorkST) on Service Performance (SERPER) through motivation is 0.17 , the total direct and indirect effect (DCE + ICE) is 2.18.

\section{First Hypothesis}

There is a positive and significant influence of Transformational Leadership (LTRAN) on work motivation (MOTIV) of employees at PT. Meritindo Sejahtera Jakarta.

The coefficient of direct influence of Transformational Leadership (LTRAN) on Work Motivation (MOTIV) of PT. Meritindo Sejahtera Jakarta is 0.46, while the error value (se pk) of 0.20. If the regression coefficient value of the latent variable LTRAN to MOTIV is 0.46 divided by the error value (se pk) 0.20 , thevalue $\mathbf{T}$ of 2.3 or $\mathbf{T}$ value generated by the full path diagram output is 2.24 . Because the value of $\mathbf{T}>$ of the critical value of 1.96 , it can be concluded that the coefficient of direct influence of Transformational Leadership (LTRAN) on Work Motivation (MOTI) issignificant, with an error variance $=0.5$ and a coefficient of determination $\mathrm{R}^{2}$ of 0.55 . Thus, the first hypothesis stating the positive and significant influence of Transformational Leadership (LTRAN) on Motivation (MOTIV) can be accepted.

\section{Second Hypothesis}

There is a positive and significant influence of Work Stress (WorkST) on Work Motivation (MOTIV) of employees at PT. Meritindo Sejahtera Jakarta.

The coefficient of direct influence of Work Stress (WorkST) on Work Motivation (MOTIV) is 0.30 , while the error value (se pk) equal to 0.19 If the regression coefficient value of the latent variable Work Stress (WorkST) to MOTIV is 0.30 divided by the error value (sepk) of 0.19 , avalueobtained $\mathbf{T}$ of 1.57 is. or according to the calculated P-Value on the diagram output of 1.62 . Because the value of $\mathbf{T}<1.96$, it can be concluded that the coefficient of direct influence of Work Stress variables on Work Motivation is not significant, with an error variance of 0.45 and a coefficient of determination of $R^{2}$ of 0.55 . 
Thus, the second hypothesis stating the positive and significant influence of Work Stress (WorkST) on Motivation (MOTIV) cannot be accepted.

\section{Third Hypothesis}

There is a positive and significant influence of Work Motivation (MOTIV) on Service Performance (SERPER) at PT. Meritindo Sejahtera Jakarta

The coefficient of direct influence of Work Motivation (MOTIV) on Service Performance (SERPER) is 0.53 , while the error value (se pk) of 0.13 . If the value of the latent variable regression coefficient of Service Performance (SERPER) to Work Motivation (MOTIV ) is 0.53 divided by the error value (sepk) of 0.13 , avalueobtained $\mathbf{T}$ of 4.08 or according to the output path diagram of 4.04 is. Because the value of $\mathbf{T}>1.96$, it can be concluded that the coefficient of direct influence of Work Motivation variables on Service Performance is significant, with an error variance of 0.18 and a coefficient of determination of $\mathrm{R}^{2}$ of 0.81 . Thus, the third hypothesis stating the positive and significant influence of Work Motivation (MOTIV) on Service Performance (SERPER) can be accepted.

\section{Fourth Hypothesis}

There is a positive and significant effect of work stress (WorkST) on service performance (SERPER)

The coefficient of direct influence of Work Stress (WorkST) on Service Performance (SERPER) is 0.16 , while the error value (se pk) of 0.13. If the value of the latent variable regression coefficient of Service Performance (SERPER) to Work Motivation (MOTIV) is 0.53 divided by the error value (sepk) of 0.15 , avalueobtained $\mathbf{T}$ of 3.53 is. Because the value of $\mathbf{T}>1.96$, it can be concluded that the coefficient of direct influence of the Work Stress variable (WorkST) on Service Performance (SERPER) is significant, with an error variance of 0.18 and a coefficient of determination of $\mathrm{R}^{2}$ of 0.81 . Thus, the third hypothesis which states the positive and significant effect of Work Stress (WorkST) on Service Performance (SERPER) can be accepted.

\section{Fifth Hypothesis}

There is a positive and significant influence of Transformational Leadership (LTRAN) on Service Performance (SERPER)

The direct effect coefficient on Transformational Leadership (LTRAN) on Service Performance (SERPER) is 0.30, while the error value (sepk) is 0.17 . If the regression coefficient value of the latent variable Transformational Leadership (LTRAN) to Service Performance (SERPER) is 0.30 divided by the error value (sepk) of 0.17 , avalueobtained $\mathbf{T}$ of 1.76 is. Because the value of $\mathbf{T}<1.96$, it can be concluded that the coefficient of direct influence of Work Motivation variables on Service Performance is not significant, with an error variance of 0.18 and a coefficient of determination of $\mathrm{R}^{2}$ of 0.8 . Thus, the third hypothesis stating the positive and significant influence of Transformational Leadership (LTRAN) on Service Performance (SERPER) cannot be accepted. 


\section{Discussion}

\section{The positive influence of Transformational Leadership on Employee Motivation of PT. Meritindo Sejahtera Jakarta}

The results of this study prove that Transformational Leadership (LTRAN) has a positive and significant effect on motivation on employees of PT Meritindo Sejahtera Jakarta. The relationship between the influence of transformational leadership and motivation has a standardized total effects of 0.46 , which states that there is a positive and significant influence of Transformational Leadership (LTRAN) on Motivation (MOTIV). The results of this study are confirmed by the results of the research conducted by Tucunan et al. (2014),

Transformational leadership is a style of a leader that can encourage others to be similar or in accordance with him, inspirational motivation is a situation where individuals give an idea or inspiration for others to follow it, intellectual stimulation characterizes the behavior where individuals give challenges to argue or take other risks to employees and individual consideration, namely behavior where individuals try to meet and understand the needs of their employees. An individual's motivation to achieve something or achieve the goals he wants is closely related to the model that he accepts or likes. When an individual finds the right raw model according to himself and inspires himself, the hard work and behavior of an individual will try to be similar to what inspires an individual employee so that everything will be sacrificed to follow in the footsteps of his raw model. Just like an employee who is inspired by a leader and makes his leader a raw model, that employee will observe, imitate and even modify in order to get better results. The results of research at PT. Meritindo Sejahtera Jakarta proves that the theory put forward by experts and previous researchers about the relationship of transformational leadership with employee motivation can be accepted. Where if we see from the results of the study confirm that the leadership at PT. Meritindo Sejahtera Jakarta can inspire its employees. A decrease in the number of customers at PT. The significant Meritindo Sejahtera Jakarta was theoretically not in line with the findings of this discovery. Significant customer decline that occurred at PT. Meritindo Sejahtera Jakarta needs to be re-examined with broader factors and other variables.

\section{Positive Influence of Transformational Leadership on Employee Service Performance of PT.Meritindo Sejahtera Jakarta}

The results of the study prove that transformational leadership has only a positive but not significant effect as seen from the results of the coefficient of the direct influence of transformational leadership (LTRAN) on service performance (SERPER) of only 0.30, and the value of $\mathrm{T}<1.96$. These results confirm to us that the transformational leadership style does not always have a significant effect on service performance. As the opinion that states that "transformational leadership style can improve the performance of its employees. This influence is very central to the performance of an employee. Good and bad performance of an employee one of the factors is the attitude and behavior of a leader ". Kharis (2015), Tampi (2014). This insignificance is because there are several factors that affect the performance of employee services, the skills of an individual employee in carrying out their duties, the knowledge of an individual employee in performing his duties and the workload he receives as opinions expressed (Dhar, 2015), "service performance is a result of 
differences between expectations and the results obtained by the company as a result of employee performance ".

Based on that service performance is the result of various factors that influence employees to get results / achieve shared goals that are influenced by the skills, knowledge of individual employees and skills in carrying out their duties. Therefore the case that occurred at PT. Meritindo Sejahtera Jakarta, where the results of the study show the insignificance of the effect of performance on service must be seen to what extent the company has improved the skills, knowledge of employees about their work. A decrease in customers at PT. Meritindo Sejahtera Jakarta within a certain period should be suspected that the lack of appearance of employees in carrying out tasks as one of the causes.

\section{The effect of work stress has an effect on motivation on the employees of PT. Meritindo Sejahtera Jakarta}

The results of the study the coefficient of direct influence Work Stress (WorkST) on Work Motivation (MOTIV) of 0.30, with a T value of 1.57. Because the value of $\mathrm{T}<1.96$, it can be concluded that the coefficient of direct influence of Work Stress variables on motivation workis not significant. Thus, the results of a study stating the existence of a positive and significant effect of Work Stress (WorkST) on Motivation (MOTIV) cannot be accepted. These results also reject the results of research conducted by (Loghan : 2015) and Rivai (2016). work stress is a condition of tension that creates physical and psychological imbalances, which affect emotions, thought processes, the condition of an employee ". Istijanto argues that, "stress arises when employees are unable to meet the demands of the job. Lack of clarity about what is the responsibility of the job, lack of time to complete the task, there is no support facilities to carry out the work, conflicting work tasks, is a stress trigger but there is also an individual employee will be increasingly triggered by this condition. The existence of tension, pressure for an individual employee is a separate challenge that must be overcome and motivates the emergence of motivation to move forward better. Like the results of this study can be interpreted that the work press or work disability may not necessarily encourage the loss of motivation to work better for an employee but motivation will arise if a company leader provides support and opportunities for growth for all individual employees in the company. Like the results of research at PT. Meritindo Sejahtera Jakarta that work stress might encourage motivated employees to improve better performance.

\section{Job Stress negatively affects service performance on the employees of PT Meritindo Sejahtera Jakarta}

The results of this study prove that there is a significant negative effect of work stress on the work productivity of the employees of PT Meritindo Sejahtera Jakarta,. The results showed that work stress as one of the factors that can reduce the quality of employee service performance at the company. For companies the consequences arising from stress are increased absenteeism, decreased productivity, and can psychologically reduce organizational commitment, trigger feelings of alienation, and turnover ". This is supported by the results of research conducted by Tanjung \& Hutagalung [24] and in accordance with the opinion of Cooper \& Straw [25] assuming stress symptoms can affect work productivity, because factors 
that are the source of work stress include physical, behavioral, character, personality, emotional, intellectual, and interpersonal.

\section{Motivation has a positive effect on service performance of PT Meritindo Sejahtera Jakarta employees}

The results of this study prove that there is a significant positive effect of motivation on productivity on employees of PT Meritindo Sejahtera Jakarta. The results of this study are in line with Tindow et al. (2014), Hanafi \& Yohana (2017) which shows that the motivation variable has a positive and significant effect on the Service Performance variable of PT Meritindo Sejahtera Jakarta employees.

\section{CONCLUSION AND SUGESTION}

\section{Conclusions}

The results of this study reinforce the theory that:

1) There is a positive and significant effect of service performance on motivation where these results are confirmed by theory and the results of previous studies.

2) There is no significant effect of work stress on work motivation on PT Meritindo Sejahtera Jakarta employees

3) There is a significant influence of work motivation on the service performance of employees of PT Meritindo Sejahtera Jakarta

4) There is a significant effect of work stress on the performance of service of employees of PT Meritindo Sejahtera Jakarta

5) There is no significant influence of transformational leadership on the service performance of PT Meritindo Sejahtera Jakarta

\section{Suggestion}

1) To get a comparison and strengthen the theory of influencing among the variables studied, it is necessary to do a research or review using different research objects or in the same industry with different locations as in other areas in Jakarta.

2) Future studies can use a wider and wider number of samples, and add references and more recent research reviews so that research results are accurate.

3) In future studies, research variables can be added such as job satisfaction, career development, compensation that can be investigated as well as whether these variables can affect motivation and performance. 


\section{REFERENCES}

1. COLQUITT, Lepine; WESSON, Organizational Behavior. Improving Performance and Commitment in The Workplace. Florida: McGraw-Hill Irwin, 2009.

2. SLOCUM, John W ; HELLRIEGEL, Don. Principles of organizational behavior. Mason, OH: South-Western Cengage Learning, 2009.

3. MUIZU, Wa Ode Zusnita; KALTUM, Umi; SULE, Ernie T. The influence of leadership on employee performance. PERWIRA-Journal of Indonesian Entrepreneurship Education, 2019, 2.1: 70-78.

4. TJIPTONO, Fandy; CHANDRA, Gregory. Service Management Improving Service Prime. Jakarta: Andi, 2012.

5. Suharyono, S. Alu, H. (201). The Influence of Motivation, Discipline and Leadership Style on Work Performance of the Social Workers and Transmigration Offices of Batang Hari Regency ". Journal Batanghari University Scientific

6. DHAR, Rajib Lochan, MITTAL, Swati; Transformational leadership and employee creativity: mediating the role of creative self-efficacy and moderating the role of knowledge sharing. Management Decision, 2015, 53.5: 894-910.

7. KINICKI, A .; KREITNER, R. Organizational behavior: Key concepts skills and practices. New York: McGraw / Irwin, 2008.

8. Eriyanto. (2011). Content analysis: Introduction to the methodology for communication research and other social sciences. Jakarta: Kencana Prenada Media Group

9. Siswanto, HB (2009). Introduction to management (5th ed.). Jakarta: Earth Literacy.

10. MICKAHAIL, HYNES, Rilla ; Bethany K. Leadership, culture, and innovation. In: Effective and Creative Leadership in Diverse Workforces. Palgrave Macmillan, Cham, 2019. p. 65-99.

11. GIBSON, Kerry; CARTWRIGHT, Claire; READ, John. 'In my life antidepressants have been ...': a qualitative analysis of users' diverse experiences with antidepressants. BMC psychiatry, 2016, 16.1: 135.

12. ERIANTO, Feri. THE INFLUENCE OF ORGANIZATIONAL CLIMATE AND WORK MOTIVATION ON EMPLOYEE PERFORMANCE OF WEST JAVA PLANTATION PLANTATIONS. 2015. PhD Thesis. Indonesian education university.

13. RIVAI, Veithzal. Human resource management for companies. 2016.

14. Robbins, Stephen, P and Timothy A. Judge., (2008). Organizational Behavior Volume I \& II, Indonesian Edition, Linguists

, Index Team, PT Gramedia Group Index, Jakarta.

15. HASIBUAN, Malayu SP. Basic management, understanding, and problems. 2019.

16. Semaksiani. Astria,et.al(2019); The Effect of Work Loads and Work Stress on Motivation of Work Productivity (Empirical Case Study of Ink-Producing Companies). DOI: 10.36348 / SB.2019.v05i10.00X. Scholars Bulletin Abbreviated Key Title: Sch Bull ISSN 2412-9771 (Print) | ISSN 2412-897X (Online) Middle East Publishers Scholars, Dubai, United Arab Emirates Journal homepage: http://scholarsbulletin.com/

17. TUCUNAN, Roy Johan Agung; SUPARTHA, Wayan Gede; RIANA, I. Gede. The Effect of Transformational Leadership on Employee Motivation and Performance. E-Journal of Economics and Business, Udayana University, 2014, 3.9: 533-550.

18. PRADITA, Mokhamad Yanuar. The effect of compensation, leadership style and characteristics of marketers on the motivation and performance of marketers in pt. Bank Rakyat Indonesia (Persero) tbk. Jombang branch. Journal of Business and Management, 2017, 4.2. 
19. ZAREEN, Memoona; RAZZAQ, Kiran; MUJTABA, Bahaudin G. Impact of transactional, transformational and laissez-faire leadership styles on motivation: A quantitative study of banking employees in Pakistan. Public Organization Review, 2015, 15.4: 531-549.

20. DESCHAMPS, Carl, et al. Transformational leadership and change: How leaders influence their followers' motivation through organizational justice. Journal of Healthcare Management, 2016, 61.3: 194-213.

21. LOGAN, Gordon D. On the ability to inhibit thought and action: A users' guide to the stop signal paradigm. 1994.

22. SPENCER, Rosemary; COIERA, Enrico; LOGAN, Pamela. Variation in communication loads on clinical staff in the emergency department. Annals of emergency medicine, 2004, 44.3: 268-273.

23. KHARIS, Indra. The influence of transformational leadership style on employee performance with work motivation as an intervening variable (study on poor branch employees of Malang East Java). Journal of Business Administration, 2015, 20.1.

24. Logan Ali, AYS, Ali, AA, \& Adan, AA (2013). Working conditions and employees' productivity in manufacturing companies in Sub-Saharan African Context: Case of Somalia. Educational Research International, 2 (2), 67-78.

25. TAMPI, Bryan Johannes. The Effect of Leadership Style and Motivation on Employee Performance at PT. Bank Negara Indonesia, tbk (regional sales manado). ACTA DIURNA COMMUNICATION, 2014, 3.4.

26. MASSIE, Rachel N .; AREROS, William A .; RUMAWAS, Wilhelmina. The Effect of Job Stress on Employee Performance at Manado IT Center Management Office. Journal of Business Administration, 2018, 6.002 ..

27. FITRIYAH, Sofi. EFFECT OF WORK STRESS ON EMPLOYEE PERFORMANCE IN PT. SIMPATINDO MULTI MEDIA BANDUNG. 2016. PhD Thesis. Widyatama University.

28. OEMAR, Usailan; HELL, Leo. The Effect of Job Stress on Employee Performance in the Regional Income, Finance and Asset Service of Musi Banyuasin Regency. Global Ecoment Journal, 2017, 2.2.

29. DEWI, K. Ayu Budiastiti Purnama; WIBAWA, I. Made Artha. Effect of Job Stress on Turnover Intention Mediated by Job Satisfaction of AJB Bumiputera's 1912 Agent. EJournal of Management, 2016, 5.6.

30. TINDOW, Mohammad Iman; MEKEL, Peggy A ; SENDOW, Greis M. Work Discipline, Motivation and Compensation for Effects on Employee Performance at PT. Bank of North Sulawesi Branch of Calaca. EMBA Journal: Journal of Economic, Management, Business and Accounting Research, 2014, 2.2.

31. HANAFI, Bayu Dwi Laksono; YOHANA, Corry. The influence of motivation, and work environment, on employee performance, with job satisfaction as a mediating variable at PT BNI Life Insurance. Journal of Economic and Business Education (JPEB), 2017, 5.1: 73-89.

32. HAIR, Joseph F .; RINGLE, Christian M .; SARSTEDT, Marko. Partial least squares: the better approach to structural equation modeling ?. Long Range Planning, 2012, 45.56: 312-319. 